\title{
Kaynamayan distal radius, skafoid, metakarp ve falanks kırıkları -el bileği ve elde kaynamama
}

\author{
Non-union of distal radius, scaphoid, metacarpal and phalangeal fractures \\ -non-unions of wrist and hand
}

\author{
Eftal Güdemez ${ }^{1}$, Hakan Özben², Seval Tanrıkulu² \\ ${ }^{1}$ Koç Üniversitesi Tıp Fakültesi, Ortopedi ve Travmatoloji Anabilim Dalı, İstanbul \\ ${ }^{2}$ Koç Üniversitesi Hastanesi, Ortopedi ve Travmatoloji Bölümü, İstanbul
}

Bu derleme makalede distal radius kırı̆̆ı, skafoid ve metakarp/falanks kırıkları sonrası kaynamama sorunları üzerinde durulmaktadır. Kaynamama nedenleri, tanı yöntemleri, ideal tedavi şekilleri kanıta dayalı tıp ışığında değerlendirilmektedir.

Anahtar sözcülkler: kaynamama; el kırığı; el bileği kırı̆̆ı; skafoid kaynamama

\section{EL BILEĞi VE ELDE KAYNAMAMA}

\section{Kaynamayan Distal Radius}

\section{Genel özellikler}

Anatomik olarak kemiğin dışından veya içinden damarsal beslenmesi çok iyi olan ve yapı itibariyle daha çok süngerimsi dokudan oluşan distal radiusun kırığının kaynamaması nadir görülen bir durumdur. Ayrıca distal radius kırıklarının daha çok düşük enerjili kırıklar olması ve yumuşak doku etkilenmesinin nispeten az olması da kaynamamanın az görülmesinin diğer nedenleri olabilir. Ama yaralanmaya ait olarak açık kırıklar, enfeksiyon, patolojik lezyonlar; tedaviye bağlı olarak da yetersiz redüksiyon ve uygunsuz tespit kaynamama için bilinen nedenler olarak sıralanabilir. Kaynamama hastalarının çoğunluğu daha önce ameliyat olmuş hastalardır (Şekil 1). Kemik metabolizmasını bozan kronik hastalıklar, bazı ilaçlar ve ağır sigara kullanımının da kaynamama için önemli faktörler olduğu bilinir. ${ }^{[1,2]}$

Hastalarda neredeyse kural olarak ağrılı, eğri ve instabil bir el bileği vardır. Deformite genellikle radyal
In this review article, non-union complications are evaluated after fractures of distal radius, scaphoid, metacarpal bones, and/or phalanges. The etiological factors, diagnostic tools, and optimum treatment modalities are discussed in the light of evidence based medicine.

Key words: non-union; hand fracture; wrist fracture; scaphoid non-union

eğrilik şeklindedir (Şekil 2). Genellikle distal ulnanın kırığı ve/veya çıkığı ile birlikte görülür. Normal sağıklı bir bireyde metafizyel bölgedeki bir distal radius kırığının ilk üç ayda radyografilerde ilerleyici bir şekilde kaynadığı görülmelidir. Yaralanmadan dört ay geçmesine rağmen yeterli bir kaynama görülemiyorsa gecikmiş kaynamadan, altı ay bitmesine rağmen yeterli bir kaynama olamıyorsa kaynamamadan bahsedilir. Eğer klasik radyografilerdeki kaynama incelemesinde hala şüpheler varsa bilgisayarlı tomografi (BT) ile kırık hattını geçen trabeküler kemiğin varlığı incelenip kaynama hakkında daha ayrıntılı bilgi sahibi olunabilir (Şekil 3). ${ }^{[3]}$

\section{Tedavi}

Kaynatma cerrahisi veya artrodez şeklinde yapılacak tedaviler ile ağrısız ve fonksiyon kazanmış bir el bileği oluşturulabilir. Eğer distal parça çok küçük, parçalı ve sağlıksız ise direkt artrodez planlanabilir. Artrodezin kaynaması sonrası ağrısız, stabil ve güçlü bir el bileği hastaların yaşam kalitelerine çok olumlu yansır. Eğer kemik greftlemesi ile birlikte uygun ve sağlam bir tespit

- İletişim adresi: Prof. Dr. Eftal Güdemez. Koç Üniversitesi Hastanesi, Ortopedi ve Travmatoloji Bölümü, Davutpaşa Cad. No:4, Topkapı, İstanbul Tel: 0850 - 2508250 / 0212; 44437 77; 0532 - 4646737 e-posta: egudemez@ku.edu.tr

- Geliş tarihi: 1 Kasım 2017 Kabul tarihi: 1 Kasım 2017 


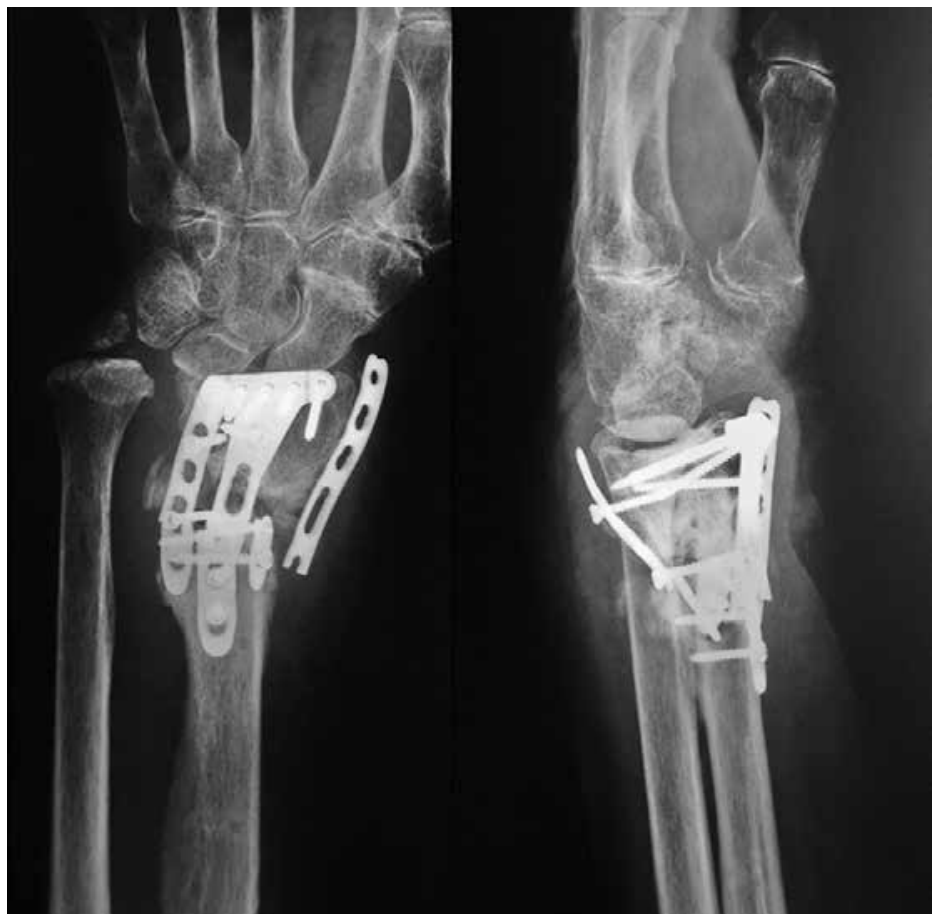

Şekil 1. Distal radius kaynamaması. Daha önce hem volar hem de dorsal yaklaşım ile plak ve vida uygulaması yapılmış.

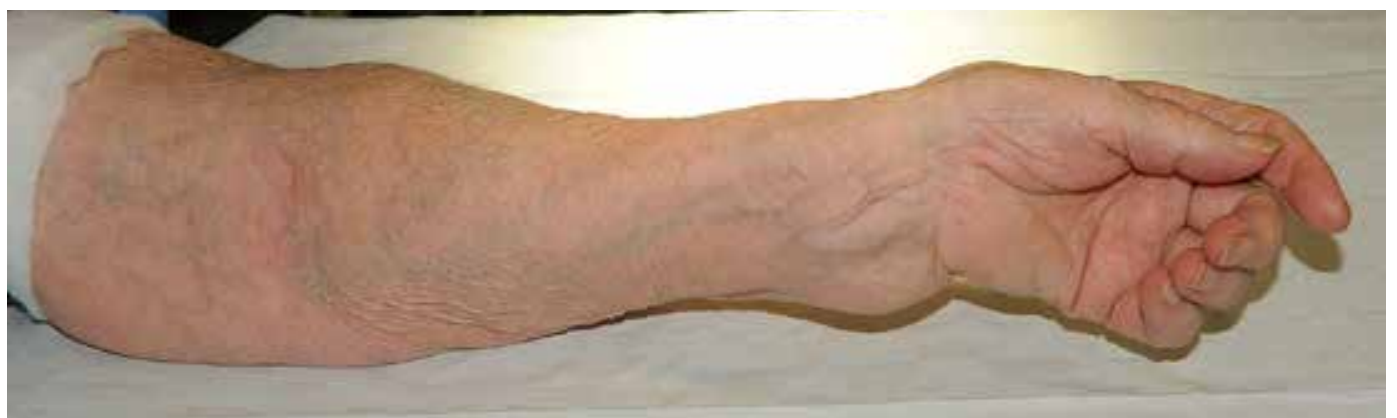

Şekil 2.

Distal radius

kaynamaması.

Deformitenin volarden görünümü.

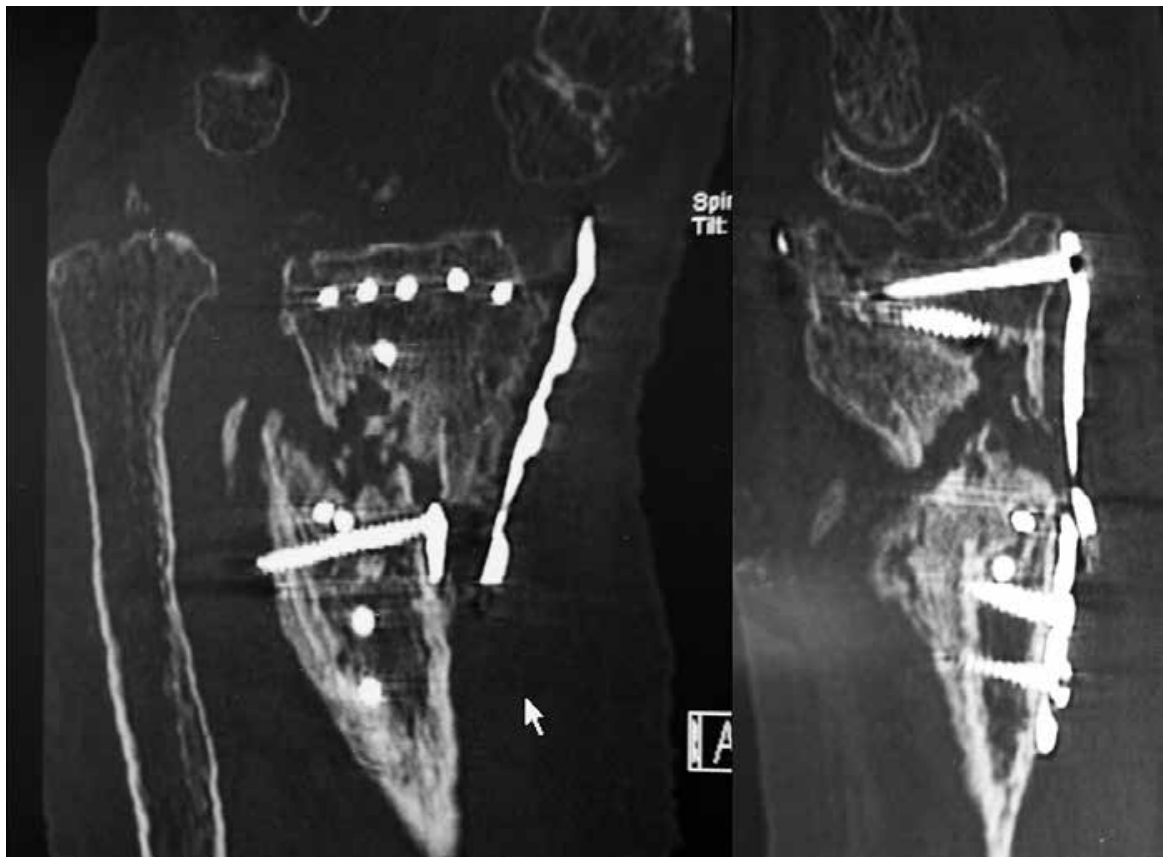

Şekil 3. Distal radius kaynamaması. Kaynamamanın BT koronal ve sagittal örnek kesitlerden görünümü. 


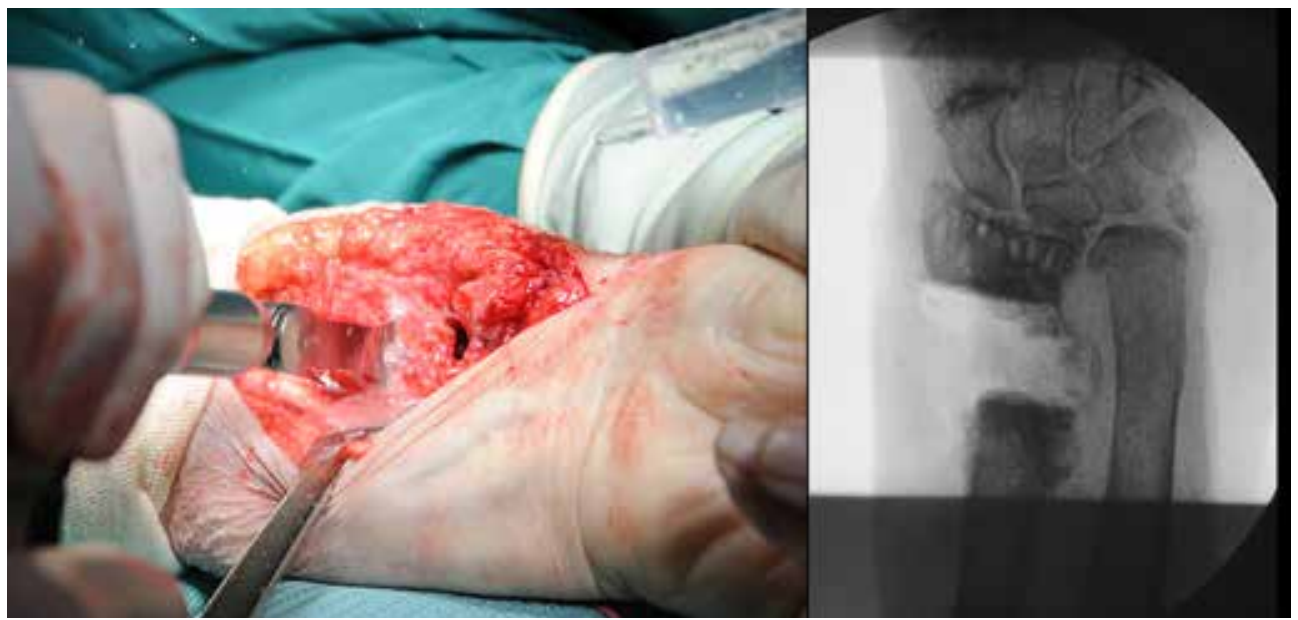

Şekil 4. Kaynamama cerrahisi. Röntgen kontrolü ile canlı kemiğe kadar yeterli rezeksiyon yapılır.

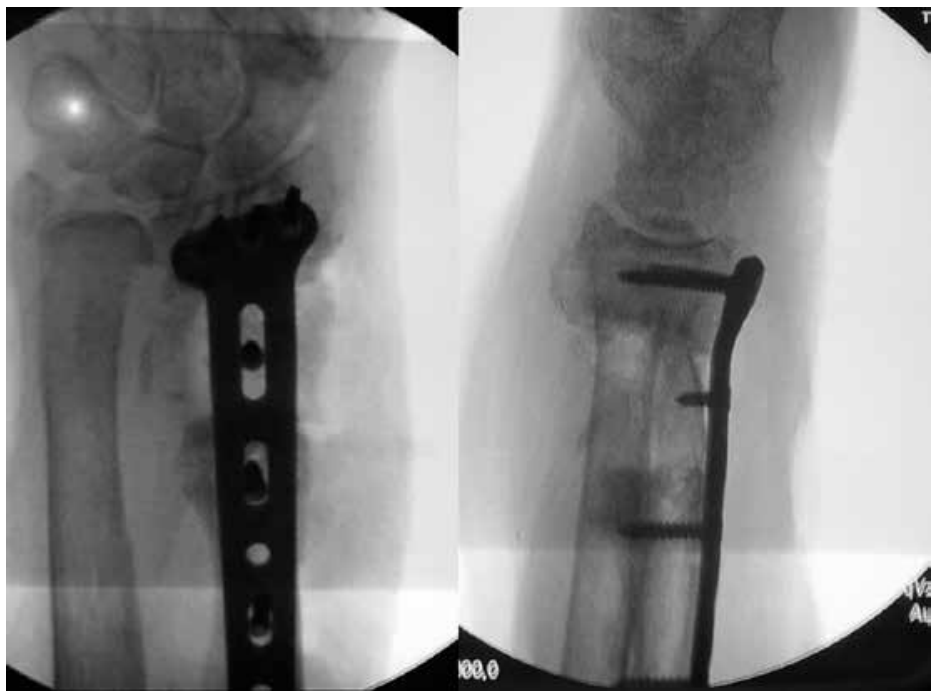

Şekil 5. Anatomik dizilim sağlanıp, kortikokansellöz greft ile desteklenip volarden kilitli plak/vida sistemi ile internal tespit yapılmış.

yapılabilecek bir distal parça varsa el bileği eklemini korumaya çalışarak kaynatma ameliyatı yapmak tercih edilmelidir. ${ }^{3]}$ Distal fragmanı 5 mm'den küçük olan hastalarla daha büyük olan hastaların kaynatma ameliyatlarının karşılaştırmalı bir çalışmasında, fonksiyonel ve radyolojik sonuçları arasında bir fark olmadığı ama küçük olanlarda daha fazla komplikasyon görüldügü rapor edilmiştir. ${ }^{[4]}$ Bu nedenlerle küçük parçanın olduğu hastalarda artrodez seçeneği daha ağır basmaktadır.

Ameliyat öncesi karşı tarafin da karşılaştırmalı görüntülemesinin yapılması, mevcut kaynamama durumuna distal radyoulnar eklemin ve ulna başının olası sorunlarının eşlik etmesinin değerlendirilmesi için önemli olacaktır. Cerrahi olarak, klasik kaynamama tedavi prensipleri distal radius için de geçerlidir (Şekil 4). Mamafih, deformitenin yönüne göre yumuşak doku gevşetmeleri, kemik greftlemesinin şekillendirilmesi ve ulnar taraf girişimleri bu bölgeye özgü durumlardır. Kısalmış ve yapışmış kas ve tendon üniteleri uzatılabilir veya kesilebilir (brakiyoradyalis gibi). Radyokarpal veya distal radyoulnar eklem konfigürasyonunun normalleştirilmesine müsaade edecek şekilde bir greft şekillendirilmesi gerekebilir. Ulna başının da hem radiusa bakan hem de karpal bölge ile olan ilişkisi normal hale getirilip, eğer dejenerasyon gibi uzun dönem sorunları ulna başını etkilemişse rezeksiyon artroplastileri de seçenekler arasına sokulabilir (Darrach veya Bowers gibi). Güncel distal ulna protezleri ise artroplasti olanağı yaratabilir. Tüm bu prensipler dahilinde, ameliyat öncesi planlama yapılırken girişim yönüne de karar verilmelidir.

Her hastaya özel olmakla beraber dorsal, volar veya ikili yaklaşımlar kullanılabilir. Anatomik restorasyonda gerekli greft kortikokansellöz olabileceği gibi tamamen kansellöz de olabilir (Şekil 5). ${ }^{[1,2]}$ Kaynamama 
tedavisinde kemik tespiti olarak güncel düşük profilli ve kilitli anatomik plak/vida sistemleri, hem dorsal hem de volar girişimlerde kullanıma izin vermektedir. Artrodez seçeneğinde ise özel el bileği artrodez plakları, hem cerrahi kolaylık açısından hem de kaynama oranlarındaki yükseklik açısından önemlidir.

\section{Sonuç}

Distal radius kaynamaması çok sık görülen bir durum değildir. Tedavisinde ameliyat öncesi iyi planlama, anatominin tekrar doğru oluşturulması ve sağlam kemik tespitleri ile kaynamada başarılı olunabilir. Kaynayan distal radiusun ağrısız ve yeterli el bileği hareket genişliği kazanması ihtimali yüksektir. Eğer el bileği artrodezi tercih edilmesi söz konusu ise ağrısız ve fonksiyonel pozisyonda güçlü bir el bileği oluşturulacaktır.

\section{Kaynamayan Skafoid}

\section{Genel özellikler}

Birçok skafoid kırığı alçı içinde tespit ile kaynayabilirken, çoğu olgu serilerinde \%10 civarında kaynamama bildirilmektedir. Skafoid, kırık hattında kayma olmadan alçı içinde pozisyonu korunabilirse \%100'e varan oranlarda kaynatılabilmektedir. Kırığın kayması durumunda (kırık parçaları arasındaki açıkıı ve yer değiştirme) \%55'lere varan kaynamama oranları bildirilmiştir. ${ }^{[5-7]}$

Kaynamama için bilinen ve yazılan risk faktörleri, bilimsel veriden daha çok geleneksel fikirler ve kanıtlanmamış bilgilerdir. Tedavi planı ve uygulaması için tanı koymadaki gecikme, önemsememe ve basit bir incinme/burkulma olarak değerlendirilme kaynamama için ciddi risk faktörleridir. Çoğu minör kayma başlangıç röntgenlerinde görülemeyebilir ve gözden kaçan bu kırıklar kaynamama için önemli bir risktir. Ayrıca proksimal kutup kırıkları kaynamama ve avasküler nekroz için yüksek risk arz eder (Şekil 6). Çünkü proksimal kutba yakın kırıklarda proksimale olan dolaşım bozulup, hem kaynama ihtimalini düşürebilir hem de proksimal parçanın avaskülarizasyonuna neden olabilir. ${ }^{[8,9]}$

Skafoid kırıkları genellikle erkeklerde ve 15-40 yaşları arasında görülür (Şekil 7). Kaynamazsa, çoğunlukla elinin üzerine düşme travmasından yıllar veya bir kaç on yıl geçtikten sonrası ağrısı başlar. Bu nedenle skafoid kaynamamasının çoğunlukla asemptomatik/minimal semptomatik olduğu veya hastaların zamanla semptomlara adapte oldukları söylenebilir. Bununla beraber semptomlar olarak yazılabilecek şikayetler; el bileği hareket genişliğinde azalma, enfiye çukurunda ve/veya skafoidin tüberkülünde ağrı/hassasiyet, dorsalde şişlik, hareket yönü sonlarında (özellikle ekstansiyonun sonunda) kalıcı ağrı ve kavrama gücü azlığıdır. ${ }^{[8]}$

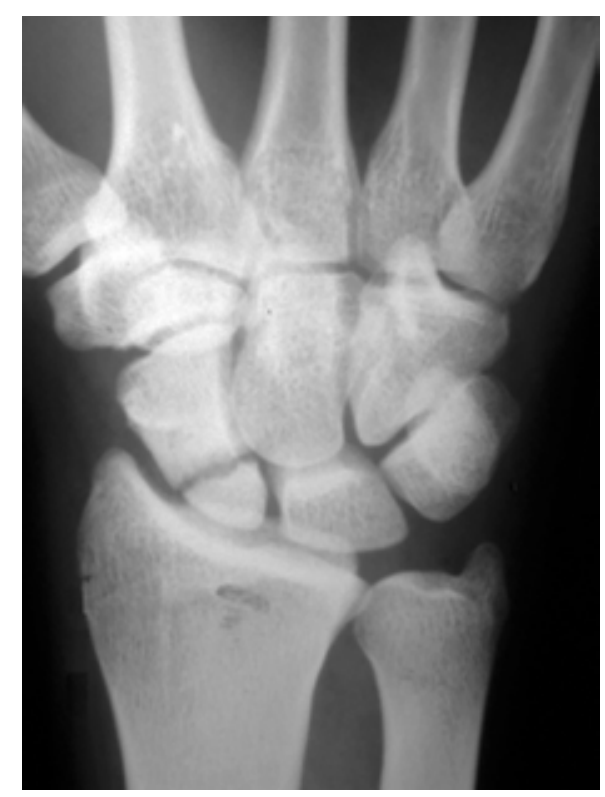

Şekil 6.

Skafoid proksimal kutup kırığı. Kaynamama ve avasküler nekroz için yüksek riskdir.

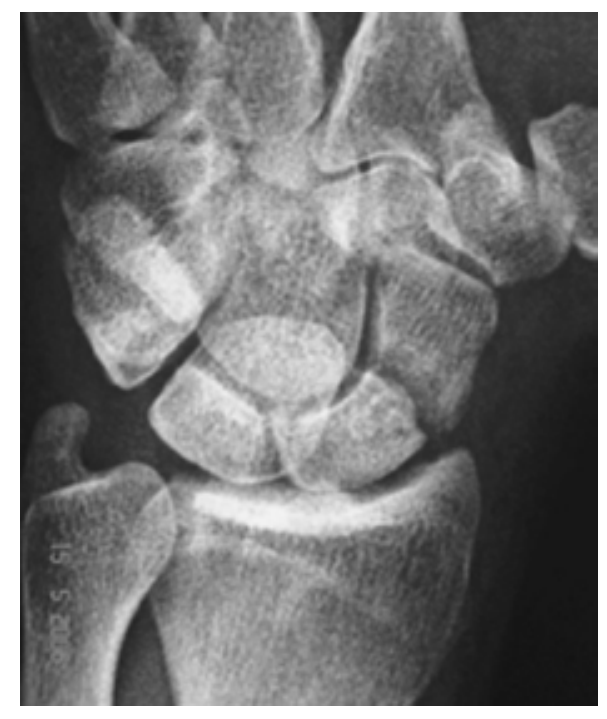

Şekil 7.

Skafoid bel bölgesinde klasik kaynamama; ön-arka görünüm.

Kaynamama hattında genişleme/açılma, parçaların birbirlerine bakan yüzlerinde skleroz ve kist oluşumları ile birlikte fark edilen deformite tipik röntgen bulgularıdır (Şekil 8). Travma sonrası ilk dört ay içinde röntgen olarak kaynamama tanısını koymak güvenilir değildir. Genellikle 6-12 ay sonra bu bulgularla tanı koymak daha mümkün hale gelir. Bununla birlikte BT ile çok daha erken tanı konulabilir. BT'nin diğer avantajı ise kemiğin anatomisinin çok ayrıntılı bir şekilde ortaya konmasıdır (Şekil 9). Ameliyat öncesi çalışılan BT ile açısal deformite, patolojik skafolunat açı, parçaların birbirlerine bakan yüzlerinde yapılacak rezeksiyon ve kullanılacak greftin boyutu çok rahat bir şekilde hesaplanabilmektedir. Manyetik rezonans (MR) 

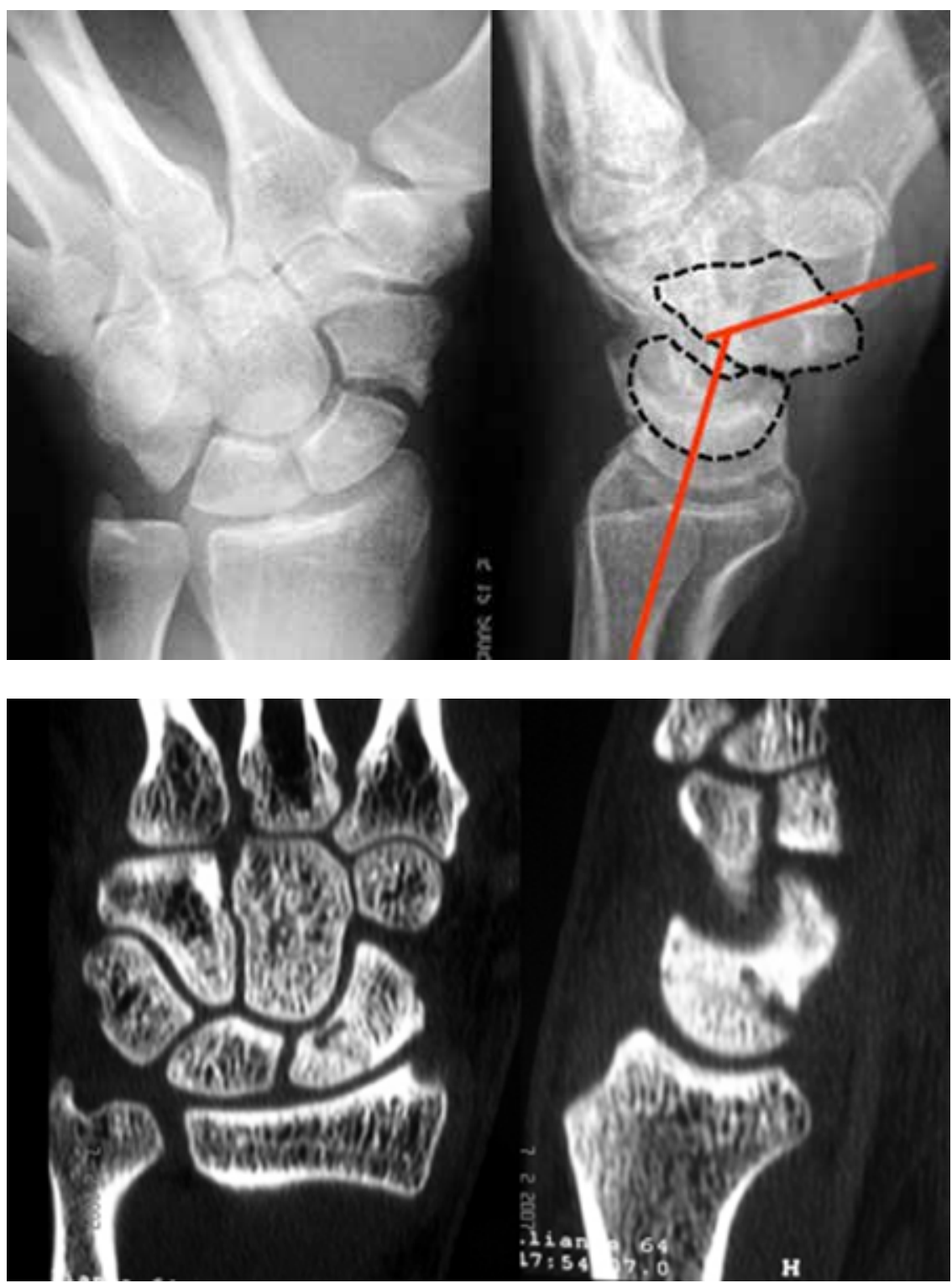

Şekil 8. Kaynamamanın röntgen bulguları. Lateral grafide klasik kamburluk deformitesi.
Şekil 9. BT görüntüsü. Kemiğin anatomisi ayrıntılı bir şekilde incelenebilir. görüntüleme ise proksimal parçanın canlılığını göstermede güvenilir bir yöntemdir (Şekil 10). ${ }^{[10-12]}$

Kaynamayan skafoidde fragmanlar arası oluşan deformite, tüm radyolojik yöntemler kullanılarak yapılan incelemelerde kolaylıkla incelenir. Kaynamama hattı kemiğin orta $1 / 3 \mathrm{kısmı} \mathrm{(bel} \mathrm{bölgesi)} \mathrm{ve} \mathrm{distalinde} \mathrm{ise}$ tepesi dorsalde olan bir açılanma deformitesi oluşur ki buna kamburluk deformitesi denir. Bu deformite çoğunlukla DISI (dorsal intercalated segmental instability) deformitesi ile birlikte görülür (Şekil 11). Eğer hat daha proksimalde ise kemikte çökme, kısalma ve radius dorsal kenarına çarpma şeklinde kendini gösterir (Şekil 12). ${ }^{[13,14]}$
Skafoid kaynamaması stabil (kararlı) veya instabil (kararsız) olabilir. Eğer kemik uzunluğunu ve şeklini koruyorsa, parçalar arasında sıkı ve sert bir fibröz doku varsa, stabil kaynamamadan bahsedilir. İnstabil kaynamamada ise kemik şeklini kaybetmiş ve karpal çökme oluşmuştur. Genellikle instabil kaynamama hızlı bir şekilde osteoartrit oluşum sürecine girer. Dejenerasyon tipik olarak önce distal skafoid parça ile radius stiloid çıkıntı arasından başlayarak midkarpal aralığa ilerler (Şekil 13). Burada da önce kapitatum ile proksimal skafoid parça arası bozulurken, ardından lunatum ile kapitatumun proksimal kutbu arası dejenere olur. Proksimal skafoid ve lunatumun distal radius ile yaptığı eklem yüzleri genellikle bozulmaz. ${ }^{[8,9]}$ 

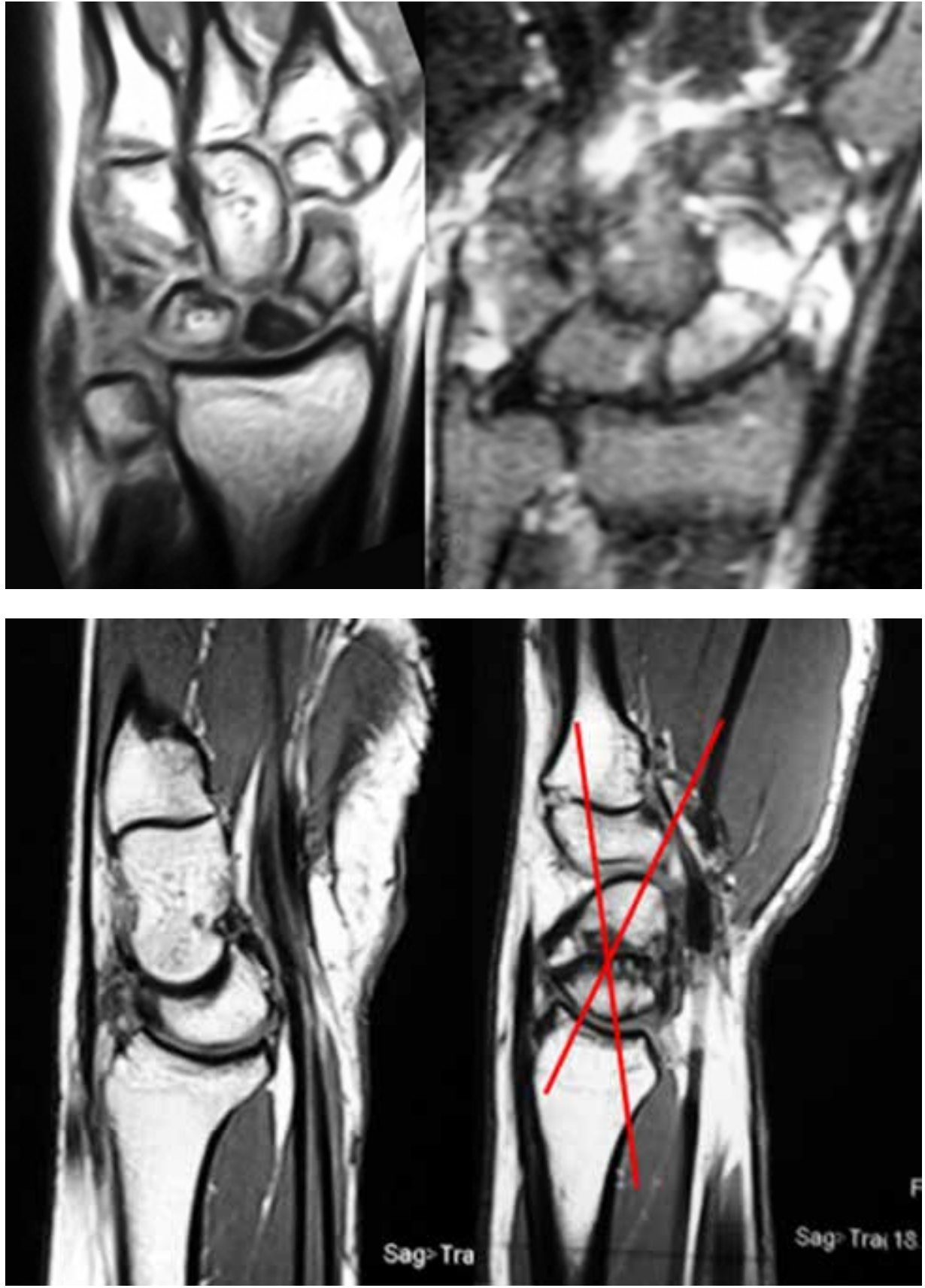

Şekil 10. MR görüntüleme. Proksimal parçanın canlılığını göstermede güvenilirdir.

Şekil 11. Sagittal kesitlerde klasik DISI ve kamburluk deformiteleri.

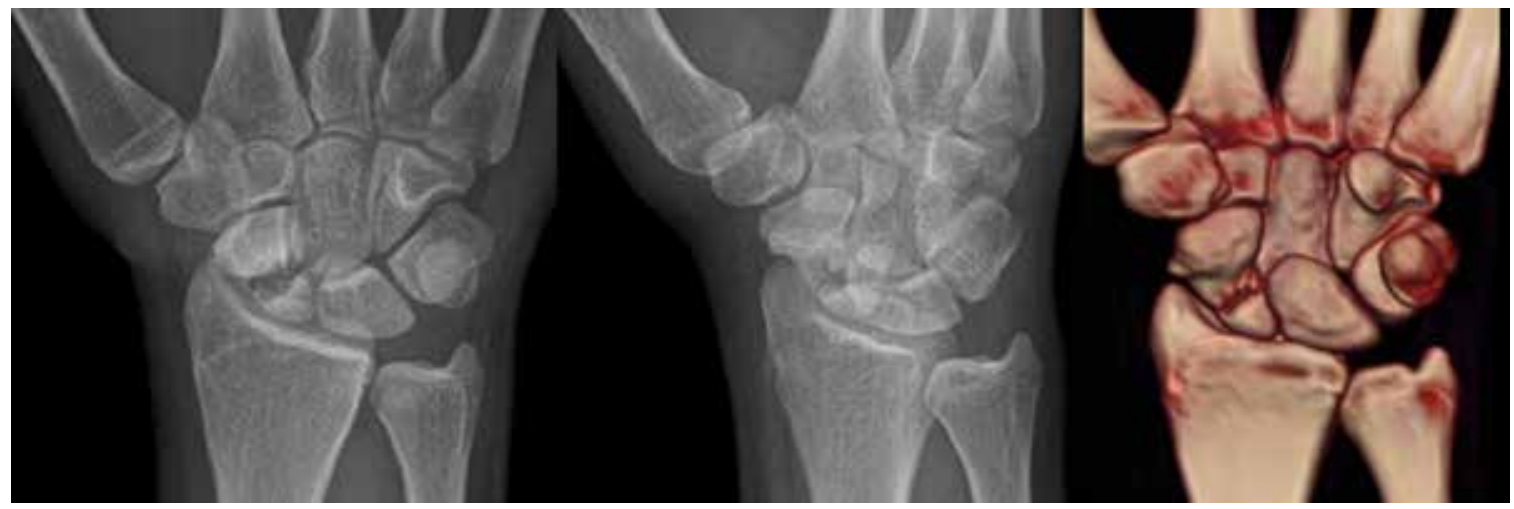

Şekil 12.

Skafoidin

radius

dorsal

kenarına

çarpması. 


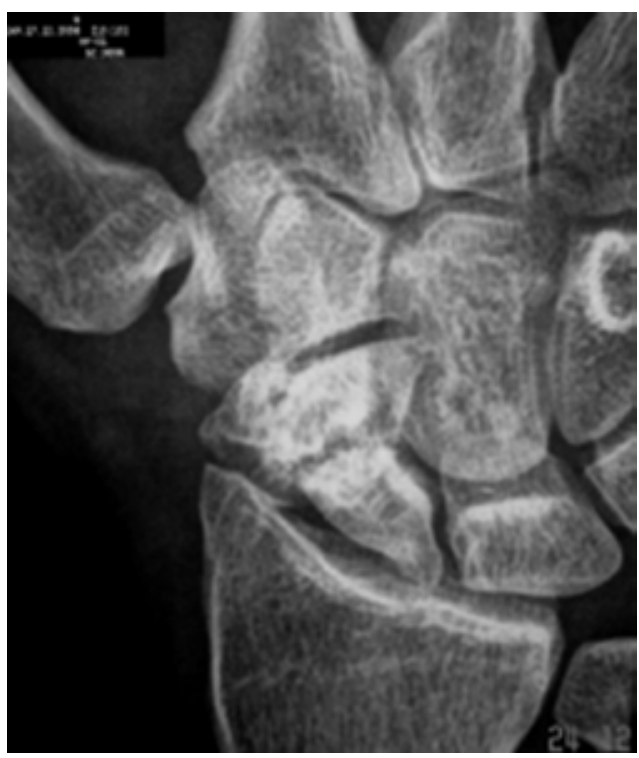

Şekil 13.

Tedavi görmemiş skafoid kaynamamasındaki osteoartrit.

\section{Tedavi}

Kaynamayan skafoid tedavisinin amacı; deformiteyi düzeltmek, kaynamayı sağlamak, şikayetleri geçirmek ve uzun vadede artrozu önlemektir. Bu hedeflere ulaşmayı zorlaştıran ve başarısızlık ihtimalini arttıran faktörler ise; kaynamama süresinin uzun olması, proksimal parçanın beslenme sorunu ve geçirilmiş başarısız ameliyat öyküsüdür. Kaynamama süresi arttıkça artroz görülme sıklığı da artmaktadır. Uzun dönem çalışmaların sonuçlarına göre, kaynama sağlanan skafoid kaynamamalarındaki artrozun ilerleyişi, kaynama sağlanamayan durumlardakine göre daha yavaştır. ${ }^{[8,15-18]}$

- Kemik Grefti Kullanmadan Yapılan Internal Tespit: Kapalı sıkıştırıcı vida kullanılarak yapılan bu yöntem, genellikle altı aydan daha az zaman geçmiş stabil / şeklini korumuş kaynamama veya gecikmiş kaynamalarda tercih edilen bir yöntemdir (Şekil 14 ve Şekil 15). ${ }^{[18,19]}$

- Kemik Greftleme: Geleneksel greftleme yöntemi Matti-Russe ameliyatıdır. Bu yöntemin değerlendirme parametresi kaynamadır. Kemiğin anatomik yapısının yeniden sağlanması değerlendirme dışıdır. Volar yaklaşımla yapılan bu teknikte her iki parçanın içi boşaltılır ve oluşan boşluğun içine spongiyöz kemik greftleriyle kortikal çubuklar yerleştirilir (Şekil 16 ve Şekil 17). Asıl teknikte herhangi bir tespit materyali yoktur ama greftleme sonrası kemik bir bütün halinde hareket etmiyorsa, bir tane Kirschner teli kullanılabilir. Bu teknik, dizilimin doğru restorasyonuna izin vermez. ${ }^{[9,17]}$
Fisk ve Fernandez, volar yaklaşımla şekillendirilmiş kortikospongiyöz greft kullanılarak, hem kemiğin hem de lunatumun dorsale dönüklüğünün (DISI) düzeltilmesine olanak veren bir greftleme tanımlamışlardır. Ameliyat öncesi planlamada, parçaların birbirlerine bakan yüzlerinden sağlıklı kemik dokusuna kadar düzgün yüzeyler oluşturacak şekilde uygun miktarda çıkarım ve temizlik yapıp, yerleştirilecek kemik greftin şekli ve büyüklüğü hesap edilir (Şekil 18 ve Şekil 19). ${ }^{[9,20]}$

Tespit, vida kullanılarak uygun bir sıkıştırma sağlayacak şekilde yapılabileceği gibi, özellikle revizyon olgularında olduğu gibi Kirschner telleri kullanılarak da gerçekleştirilebilir. Literatürde, greftleme sonrası \%80-90 oranında kaynama oranları bildirilmektedir. Bir çalışmaya göre, vida kullanılarak yapılan tespitte kaynama oranları (\%94), Kirschner telleri kullanılarak yapılan ameliyatlara göre (\%77) daha yüksek bildirilmiştir. Nispeten güvenilirliği yüksek çalışmalara göre, greftin iliak kanattan veya distal radiustan alınmasının sonuçlara etkisinin farklı olmadığı raporlanmıştır. Fakat, proksimal parçanın avasküler veya kanlanma azlığı göstermesi, kemik greftlemesinin başarısını düşürmektedir. ${ }^{[15,21-23]}$

- Damarlı Kemik Greftlemesi: Literatürde ilk tanımlanmış ilkel çalışmalarda, damarın kendisinin gömülmesi veya kemik greftinin içine damar yerleştirilmesi gibi yöntemler tanımlanmış olsa da, modern damarlı greftleme ameliyatları, distal radius üzerindeki 1,2 interkompartmantal supraretinaküler arter (1,2-ICSRA) tabanlı kaldırılan kemik adası kullanılarak yapılanlardır (Şekil 20 ve Şekil 21). Bu teknikte, \%27-100 gibi farklı oranlarda kaynatabilme sonuçları bildirilmektedir. Benzer şekilde, proksimal parçanın avaskülaritesi başarısızlığı arttırmaktadır. ${ }^{[9,24-26]}$

iliak kanattan veya distal mediyal suprakondiller femoral kondilden alınan serbest damarlı kemik greftleri de kullanılmaktadır. Karşılaştırmalı bir çalışmaya göre, serbest damarlı greftlerin 1,2-ICSRA bazlı damarlı greftlere göre istatistiksel olarak daha fazla kaynama oranları ve daha hızlı kaynama gösterdiği bildirilmiştir. ${ }^{[27,28]}$

Rastgele, kontrollü, karşılaştırmalı bir deneme çaIışması, iliak kanattan alınan şekillendirilmiş greftleme ile 1,2-ICSRA bazlı damarlı greftleme sonuçları arasında kaynama oranları, süreleri ve fonksiyonel sonuçlar arasında bir fark tespit edememiştir. ${ }^{[29]}$ Sistematik bir değerlendirme çalışmasına göre, iliak kanattan veya distal radiustan alınan kemik greftlerinin birbirlerine göre veya herhangi bir greftleme ile 


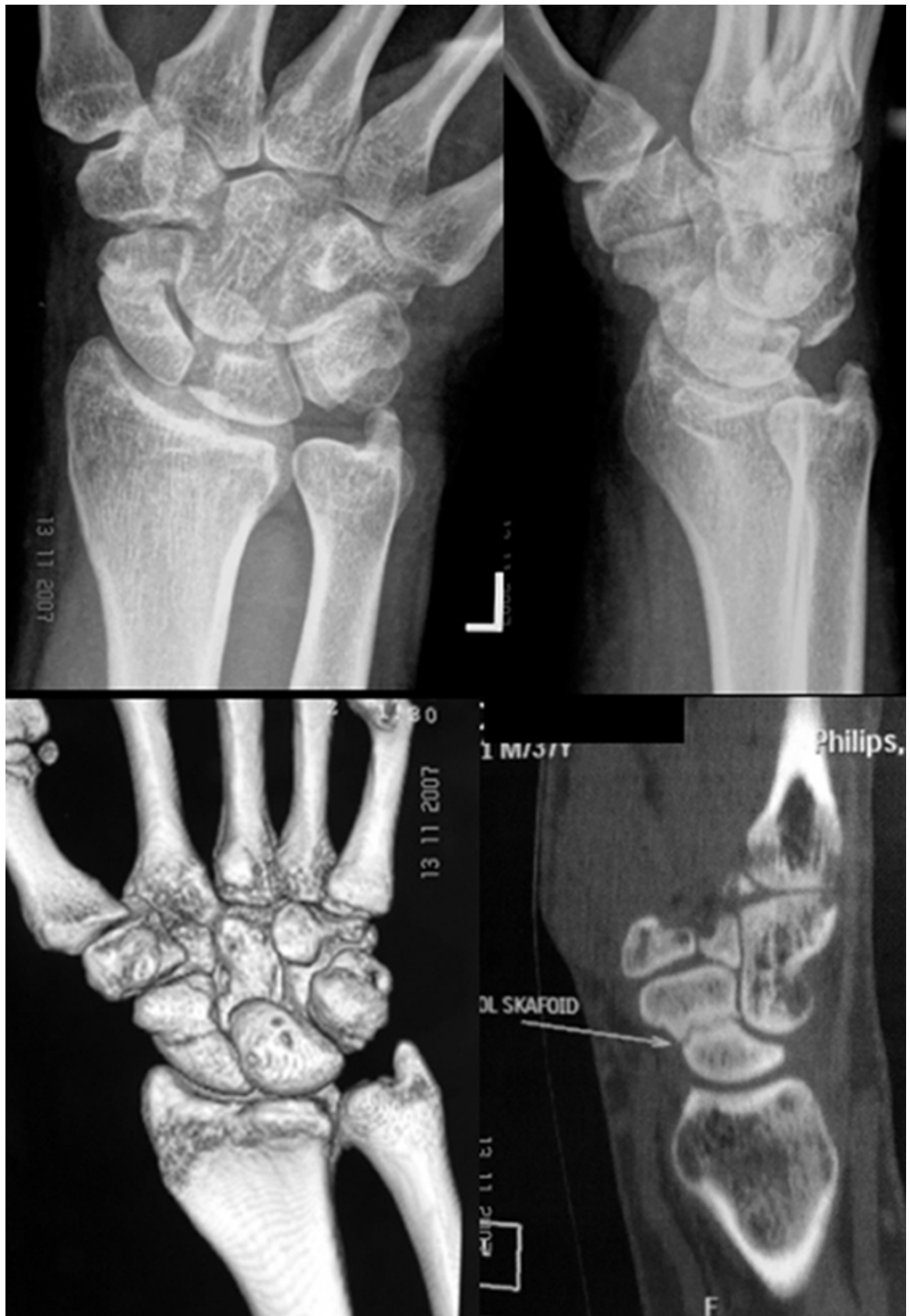

Şekil 14. Dört aylık stabil/şeklini korumuş fibröz kaynamama.

distal radius bazlı damarlı greftleme arasında kaynama oranları ve kaynama zamanları açısından hiçbir istatistiksel fark bulunamamıştır. ${ }^{[30]}$ Mamafih kanıtlar, avasküler proksimal kutbu olan skafoid kaynamamalarında damarlı kemik greftlerinin kullanılmasını desteklemektedir. ${ }^{[31]}$

- Revizyon ve Kurtarıcı Girişimler: Kaynamama için yapılan cerrahiler başarısız olursa veya kemiğin mevcudiyeti ve kalitesi yetersiz ve uygunsuz hale gelirse, başka türlü düzeltici ameliyatlar gündeme gelir ki bu uğraşılara kurtarıcı girişimler denir. Genellikle bu şartlar söz konusu olduğunda, el bileğinde bölgesel veya yaygın artroz bulguları da gözlenmektedir. Bu girişimler, el bileği denervasyonu, radyal stiloidektomi, skafoid distal kutup rezeksiyonu, proksimal sıra karpektomisi, skafoid rezeksiyonu ile 4-köşe artrodezi ve total el bileği artrodezidir. Her bir yöntemin birbirlerine göre avantajları ve dezavantajları vardır. ${ }^{[8,9,32]}$ 

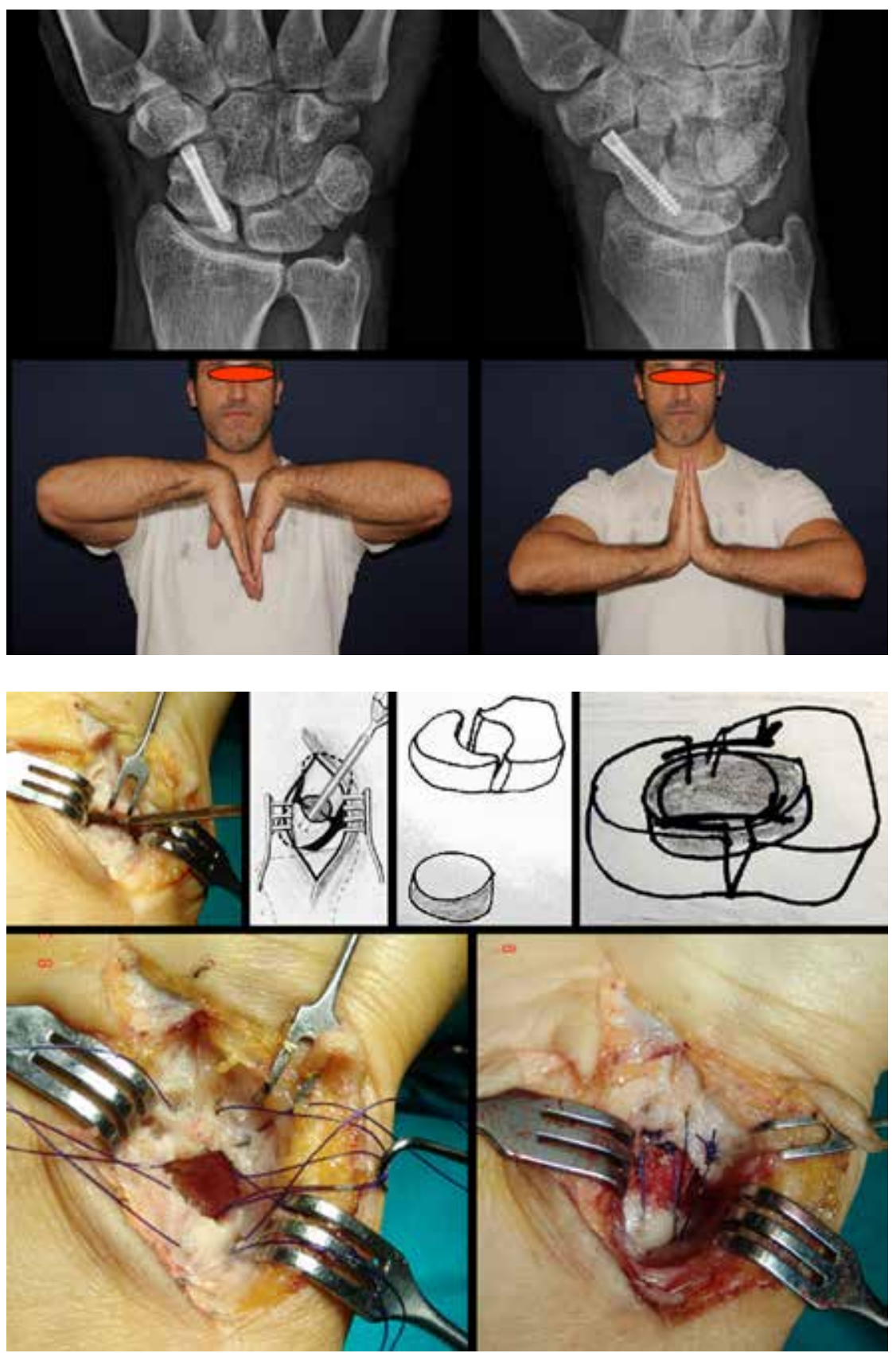

Şekil 15. Şekil 14'teki hastanın kapalı sıkıştırıcı vida kullanılarak yapılan kaynamama tedavisinin altıncı aydaki kaynamış halinin radyolojik ve fonksiyonel görüntüleri.
Şekil 16. Geleneksel Matti-Russe yöntemi. Dikiş materyalleri ile düğümleme uyarlaması.

\section{Sonuç}

Skafoid, iyileşme açısından kötü namı olan bir kemiktir. Çoğu skafoid kaynamaması instabildir ve kemiğin dizilimi/anatomik yapısı değişmiştir. Birçok tanımlanmış ve her birinin farklı avantaj/dezavantajları bulunan kaynatma ameliyatları vardır. Damarlı kemik grefti uygulamasının kaynatmadaki rolü veya kurtarıcı girişimlere geçiş konuları en tartışmalı iki konudur.

\section{Kaynamayan Metakarp ve/veya Falanks}

\section{Genel özellikler}

Elin küçük silindirik kemiklerinin kaynamama komplikasyonu nadir değildir. Travmanın kendi özelliklerine bağlı yüksek enerjili, çevre yumuşak dokularının ciddi hasar gördüğü, kirli ve açık yaralanmalarına bağlı olacağı gibi; konservatif veya cerrahi teknik yetersizliklerine, uygunsuz rehabilitasyon uygulamalarına, hastanın tedaviye uyum sorunlarına veya mevcut kronik 

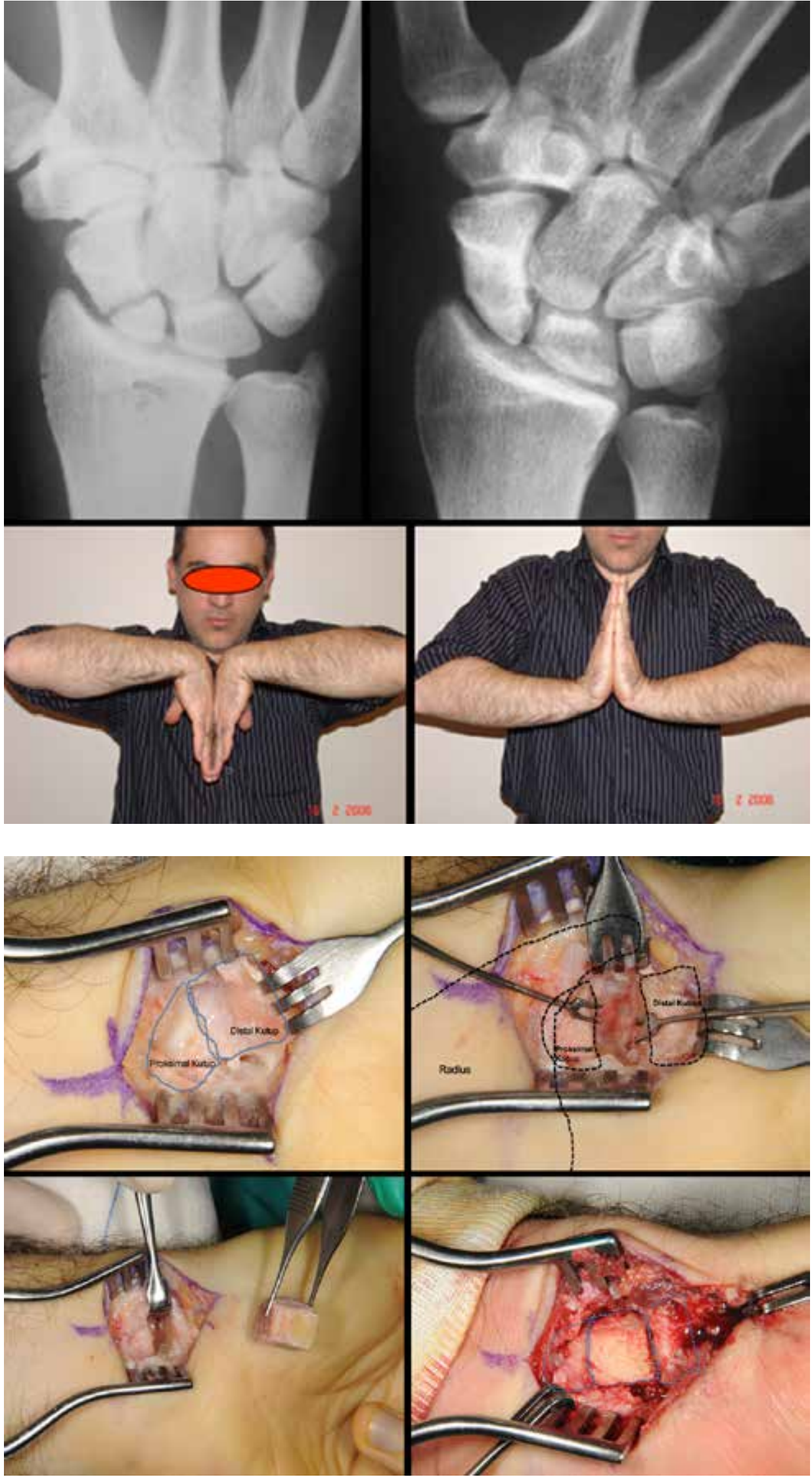

Şekil 17. Klasik Matti-Russe

yöntemi ile tedavi edilmiş bir proksimal kutup kaynamaması olgusunun kaynamış halinin radyolojik ve fonksiyonel görüntüleri.

Şekil 18. Fisk ve Fernandez volar yaklaşım ile yapılan yapısal rekontrüksiyon. 

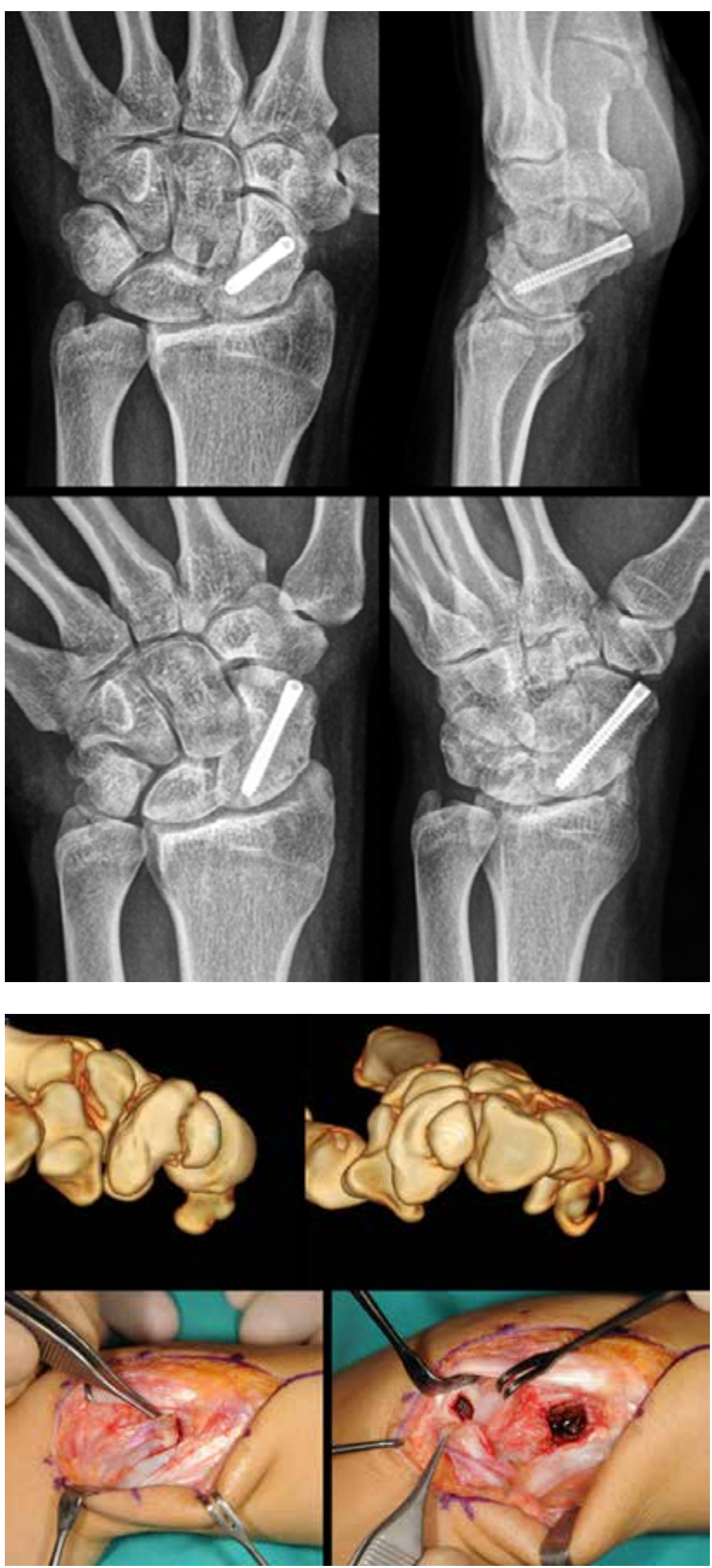

Şekil 19. Şekil 18'deki hastanın kaynamış halinin radyolojik görüntüleri.
Şekil 20. Proksimal kutup kaynamamasının üç boyutlu görüntüleri ve aynı hastada yapılan distal radiustan 1,2 interkompartmantal supraretinaküler arter tabanlı kaldırılan damarlı kemik grefti işlemi. 


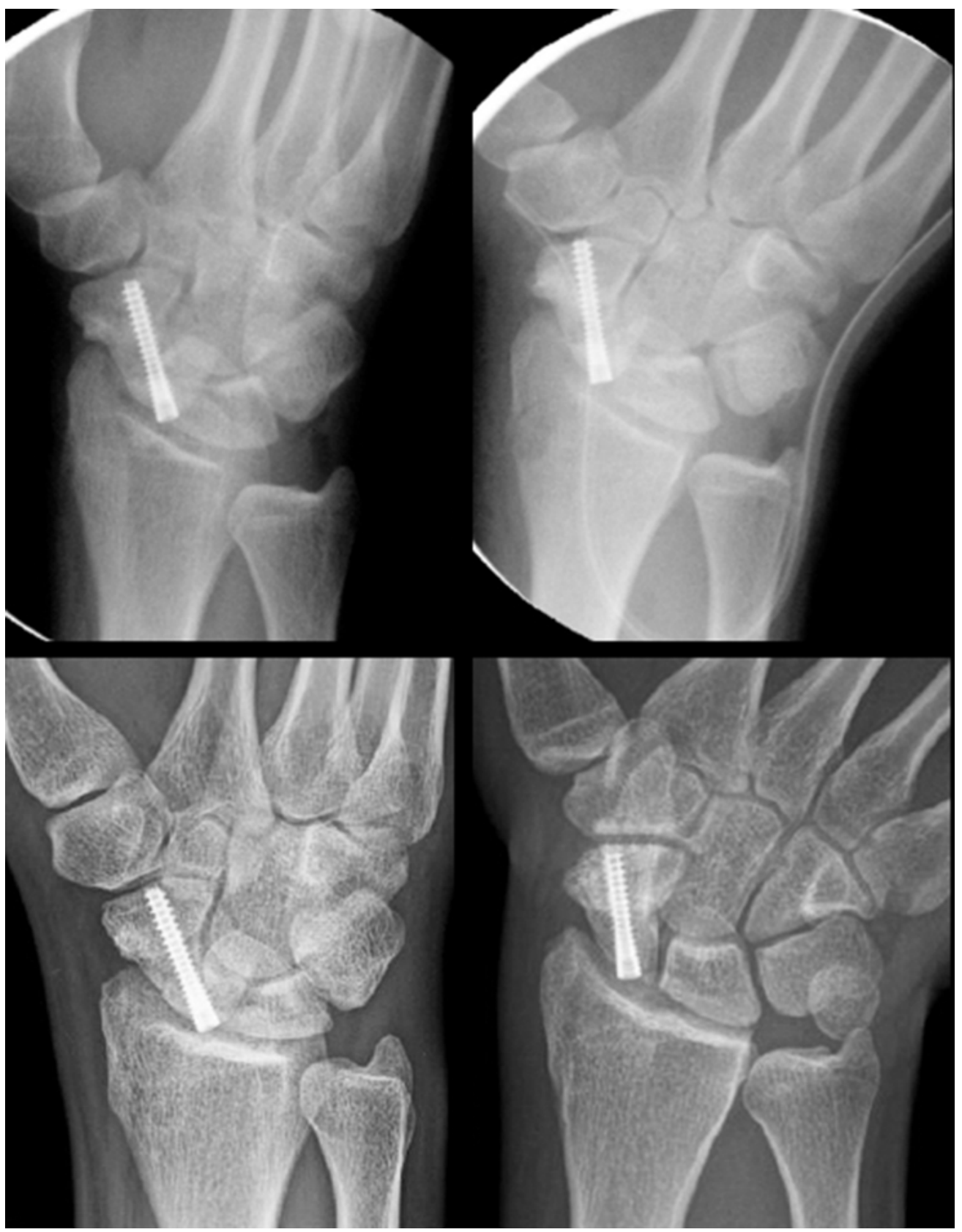

Şekil 21. Şekil 20'deki

olgunun erken ve kaynamış radyolojik görüntüleri.

rahatsızıklarına bağlı da gelişmiş olabilir (Şekil 22 ve Şekil 23). Sigara kullanımı ve enfeksiyon varlığı kaynamama için önemli risk faktörleridir. Tüm uzun kemikleri ilgilendiren kaynamamalarda olduğu gibi metakarplarda veya falankslarda da hipertrofik veya atrofik kaynamamalar görülmektedir. Atrofik kaynamamaların hepsi instabil iken, hipertrofiklerin ise çoğunluğu stabildir. ${ }^{[33,34]}$

Dördüncü ay sonunda klinik ve radyolojik olarak kaynama bulgusu yoksa kaynamama tanısı konulabilir.
Kapalı metakarp kırıklarında kaynamama komplikasyonu son derece nadirdir. Açık redüksiyon - internal tespit yöntemi ile tedavi edilmiş metakarp ve falanks kırıklarında ise \%6'ya varan oranlarda kaynamama bildirilmektedir. ${ }^{[33,35-37]}$

Kaynamama tedavisinde olmazsa olmazlar; kemiğin diziliminin sağlanması, sağlam bir kemik tespitinin oluşturulması, yeterli bir çevre doku dolaşımı, uygun bir yumuşak doku örtümü ve enfeksiyon odaklarının bütünüyle uzaklaştırılmasıdır. Hipertrofik 


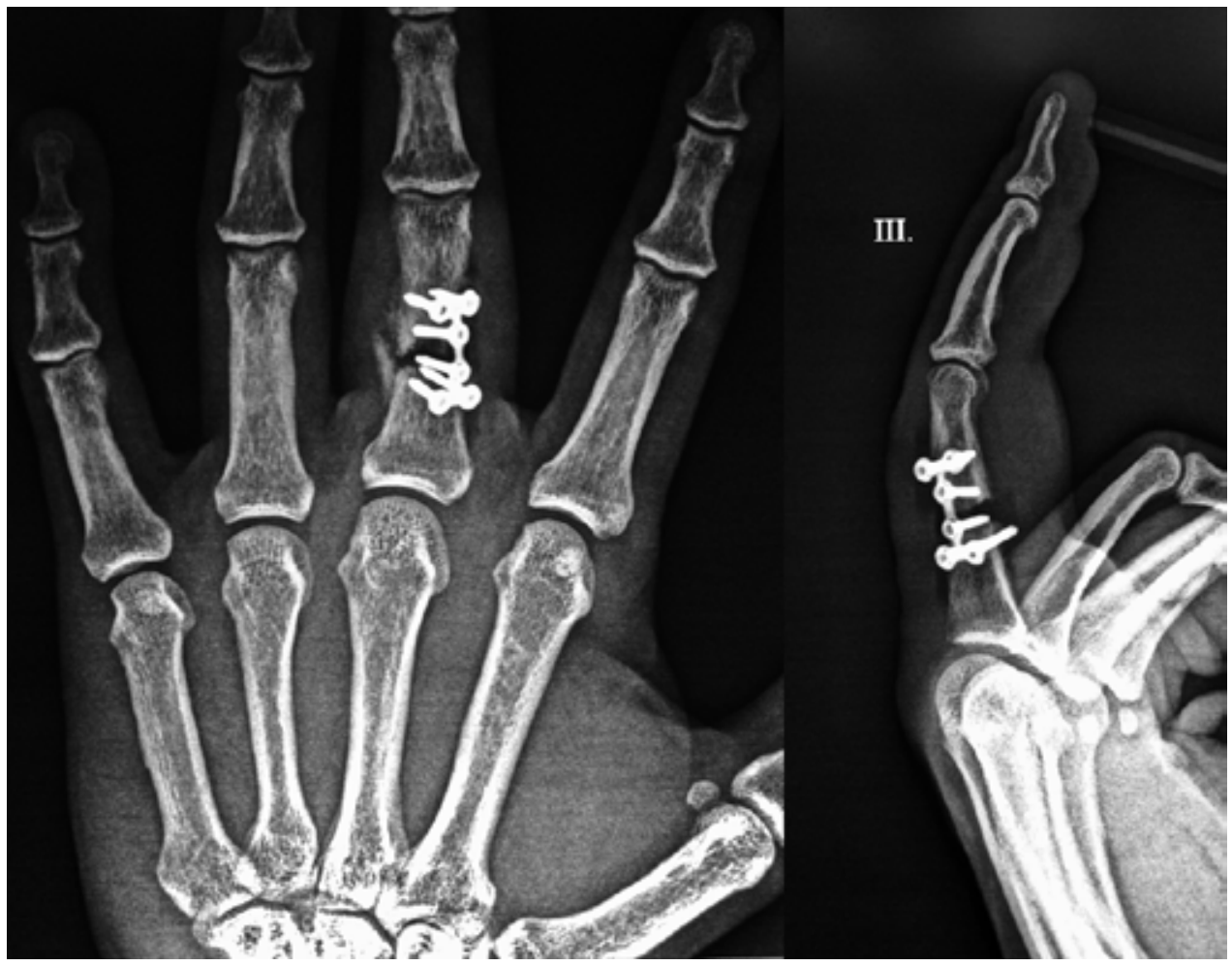

Şekil 22. Daha önce yapılmış uygunsuz cerrahi tedavi sonrası gelişmiş falanks kaynamaması.

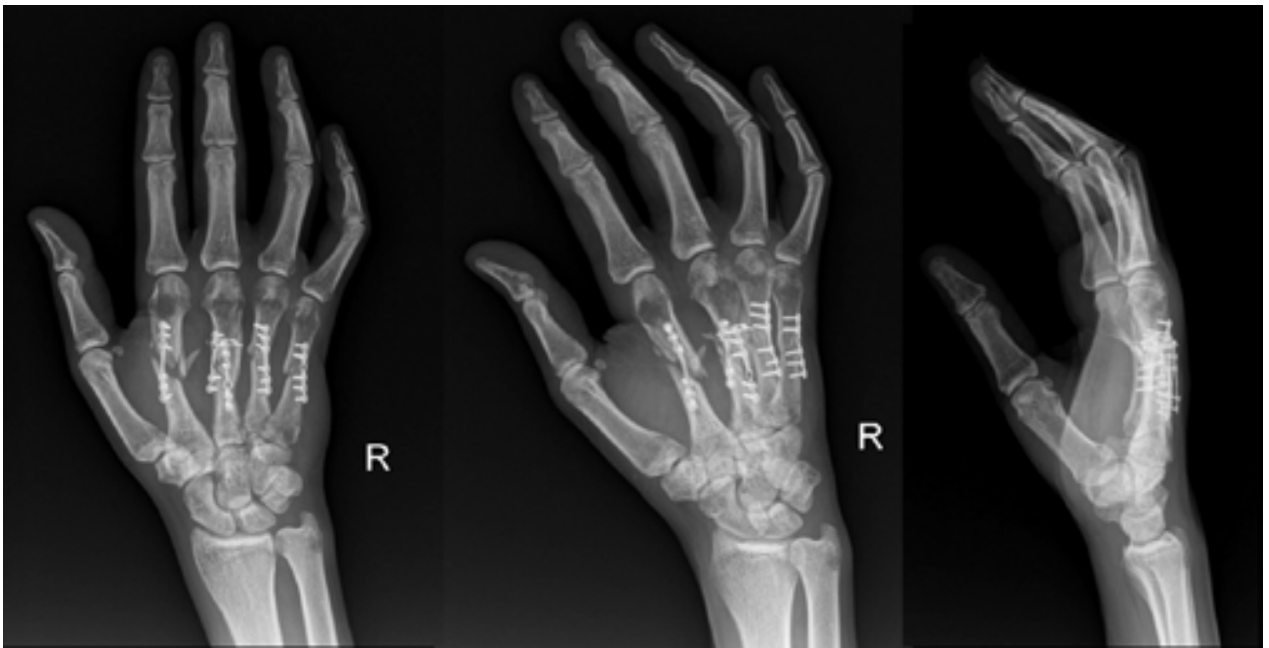

Şekil 23. Daha önce yapılmış uygunsuz cerrahi tedavi sonrası gelişmiş metakarp kaynamaması.

kaynamamalarda tedavi, tespitin çok daha sağlam gerçekleştirilmesi ile yapılır. Bu da açık redüksiyon, plak ve vidalar kullanılarak sıkıştırma altında yapılan tespit ile gerçekleştirilir. Atrofik kaynamama ise daha çok açık kırıklarda, kemik kaybı veya enfeksiyon varlığında görülür. Tedavide tüm fibröz, enfekte ve avasküler dokular agresif bir şekilde temizlenir. Arada oluşan boşluk kemik grefti kullanılarak doldurulur ve köprüleme şeklinde yapılan bir kemik tespiti ile ameliyat tamamlanır. Erken ve tam parmak hareketlerinin sağlanması çok önemlidir. Gerekirse, kaynamama cerrahisine tenoliz, artroliz gibi yumuşak doku gevşetmeleri de eklenir. Amaç, radyolojik kaynama sağlanırken tam fonksiyonel iyileşmenin de düşünülmesi ve erken rehabilitasyon programlarının planlanması olmalıdır. ${ }^{[34,38]}$

Enfeksiyonun ön planda olduğu kaynamamalarda aşamalı tedavi tercih edilebilir. Debridman ve önceki olası metal tespit materyallerinin çıkartılmasından 
sonra uygun antibiyotik tedavileri ve yara bakımı gerekir. Yumuşak ve kemik doku 4-8 hafta sonra uygun bir duruma gelirse, geç kemik greftlemesi ve kemik tespiti tercih edilebilir. Gecikilmiş, ciddi kısalık, deformite ve kontraktürlerin eşlik ettiği veya belirgin yumuşak doku eksikliklerinin var olduğu kaynamamalarda, ampütasyon veya ray rezeksiyonları tercih edilen yöntemler olabilir. ${ }^{[34,36]}$

\section{Sonuç}

Elin küçük uzun kemiklerinin kaynamama sorunları nadir değildir. Etiyoloji doğru analiz edilmeli, eşlik eden faktörler göz önünde bulundurulmalı ve tedavi yöntemi planlanırken kanıta dayalı olarak prensipler uygulanılmalı, ama kişiye özel faktörler de düşünülmelidir.

\section{KAYNAKLAR}

1. Prommersberger KJ, Fernandez DL. Nonunion of distal radius fractures. Clin Orthop Relat Res 2004;(419):51-6.

2. Ring D. Nonunion of the distal radius. Hand Clin 2005;21(3):443-7. Crossref

3. Fernandez DL, Ring D, Jupiter JB. Surgical management of delayed union and nonunion of distal radius fractures. J Hand Surg Am 2001;26(2):201-9. Crossref

4. Prommersberger KJ, Fernandez DL, Ring D, Jupiter JB, Lanz UB. Open reduction and internal fixation of un-united fractures of the distal radius fractures: does the size of the distal fragment affect the result? Chir Main 2002;21(2):113-23.

5. Dias JJ, Brenkel IJ, Finlay DB. Patterns of union in fractures of the waist of the scaphoid. J Bone Joint Surg $\mathrm{Br}$ 1989;71(2):307-10.

6. Bhat M, McCarthy M, Davis TR, Oni JA, Dawson S. MRI and plain radiography in the assessment of displaced fractures of the waist of the carpal scaphoid. J Bone Joint Surg $\mathrm{Br}$ 2004;86(5):705-13.

7. Szabo RM, Manske P. Displaced fractures of the scaphoid. Clin Orthop Relat Res 1988;(230):30-8.

8. Pao VS, Chang J. Scaphoid nonunion: diagnosis and treatment. Plast Reconstr Surg 2003:112(6):1666-76. Crossref

9. Buijze GA, Ochtman L, Ring D. Management of scaphoid nonunion. J Hand Surg Am 2012;37(5):1095-100. Crossref

10. Dias JJ, Taylor M, Thompson J, Brenkel IJ, Gregg PJ. Radiographic signs of union of scaphoid fractures: An analysis of inter-observer agreement and reproducibility. J Bone Joint Surg Br 1988;70(2):299-301.

11. Dias JJ. Definition of union after acute fractures and surgery for fracture nonunion of the scaphoid. J Hand Surg Br 2001;26(4):321-5. Crossref

12. Megerle K, Worg H, Christopoulos G, Schmitt R, Krimmer $H$. Gadolinium-enhanced preoperative MRI scans as a prognostic parameter in scaphoid nonunion. J Hand Surg Eur Vol 2011;36(1):23-8. Crossref

13. Oka K, Moritomo $H$, Murase $T$, Goto A, Sugamoto $K$, Yoshikawa H. Patterns of carpal deformity in scaphoid nonunion: a 3-dimensional and quantitative anaylsis. J Hand Surg Am 2005;30(6):1136-44. Crossref
14. Oka K, Murase T, Moritomo H, Goto A, Sugamoto K, Yoshikawa $\mathrm{H}$. Patterns of bone defect in scaphoid nonunion: a 3-dimensional and quantitative anaylsis. J Hand Surg Am 2005;30(2):359-65. Crossref

15. Tambe AD, Cutler L, Murali SR, Trail IA, Stanley JK. In scaphoid non-union, does the source of graft affect outcome? $\mathrm{Iliac}$ crest versus distal end of radius bone graft. J Hand Surg $\mathrm{Br}$ 2006;31(1):47-51. Crossref

16. Hooning van Duyvenbode JF, Keijser LC, Hauet EJ, Obermann WR, Rozing PM. Pseudoarthrosis of the scaphoid treated by the Matti-Russe operation. A long-term review of 77 cases. J Bone Joint Surg Br 1991;73(4):603-6.

17. Jiranek WA, Ruby LK, Millender LB, Bankoff MS, Newberg $\mathrm{AH}$. Long-term results after Russe bone-grafting: the effect of malunion of the scaphoid. J Bone Joint Surg Am 1992;74(8):1217-28.

18. SladeJF3rd, GeisslerWB, Gutow AP, Merrell GA. Percutaneous internal fixation of selected scaphoid nonunions with an arthroscopically assisted dorsal approach. J Bone Joint Surg Am 2003;85-A Suppl 4:20-32.

19. Mahmoud M, Koptan W. Percutaneous screw fixation without bone grafting for established scaphoid nonunion with substantial bone loss. J Bone Joint Surg Br 2011;93(7):932-6. Crossref

20. Fernandez DL. A technique for anterior wedge-shaped grafts for scaphoid nonunions with carpal instability. J Hand Surg Am 1984;9(5):733-7.

21. Merrell GA, Wolfe SW, Slade JF 3rd. Treatment of scaphoid nonunions: quantitative meta-analysis of the literature. J Hand Surg Am 2002;27(4):685-91.

22. Huang YC, Liu Y, Chen TH. Long-term results of scaphoid nonunion treated by intercalated bone grafting and Herbert's screw fixation -a study of 49 patients at least five years. Int Orthop 2009;33(5):1295-300. Crossref

23. Sayegh ET, Strauch RJ. Graft choice in the management of unstable scaphoid nonunion: a systematic review. J Hand Surg Am 2014;39(8):1500-6. Crossref

24. Zaidemberg C, Siebert JW, Angrigiani C. A new vascularized bone graft for scaphoid nonunion. J Hand Surg Am 1991;16(3):474-8.

25. Steinmann SP, Bishop AT, Berger RA. Use of the 1,2 intercompartmental supraretinacular artery as a vascularized pedicle bone graft for difficult scaphoid nonunion. J Hand Surg Am 2002;27(3):391-401.

26. Chang MA, Bishop AT, Moran SL, Shin AY. The outcomes and complications of 1,2 intercompartmental supraretinacular artery pedicled vascularized bone grafting of scaphoid nonunions. J Hand Surg Am 2006;31(3):387-96. Crossref

27. Jones DB Jr, Moran SL, Bishop AT, Shin AY. Free-vascularized medial femoral condyle bone transfer in the treatment of scaphoid nonunions. Plast Reconstr Surg 2010;125(4):117684. Crossref

28. Jones DB Jr, Bürger H, Bishop AT, Shin AY. Treatment of scaphoid waist nonunions with an avascular proximal pole and carpal collapse. A comparison of two vascularized bone grafts. J Bone Joint Surg Am 2008;90(12):2626-25. Crossref

29. Braga-Silva J, Peruchi FM, Moschen GM, Gehlen D, Padoin AV. A comparison of the use of distal radius vascularized bone graft and non-vascularized iliac crest bone graft in the treatment of non-union of scaphoid fractures. J Hand Surg Eur Vol 2008;33(5):636-40. Crossref

30. Pinder RM, Brkljac M, Rix L, Muir L, Brewster M. Treatment of scaphoid nonunion: A systematic review of the existing evidence. J Hand Surg Am 2015;40(9):1797-805. Crossref 
31. Janowski J, Coady C, Catalano LW 3rd. Scaphoid fractures: nonunion and malunion. J Hand Surg Am 2016;41(11):108792. Crossref

32. Malerich MM, Catalano LW 3rd, Weidner ZD, Vance MC, Eden CM, Eaton RG. Distal scaphoid resection for degenerative arthritis secondary to scaphoid nonunion: a 20-year experience. J Hand Surg Am 2014;39(9):1669-76. Crossref

33. Diaz-Garcia R, Waljee JF. Current management of metacarpal fractures. Hand Clin 2013;29(4):507-18. Crossref

34. Wolfe SW, Elliot AJ. Metacarpal and carpometacarpal trauma. In: Peimer CA, editor. Surgery of the Hand and Upper Extremity. New York: McGraw-Hill 1996. pp.883-920.
35. Page SM, Stern PJ. Complications and range of motion following plate fixation of metacarpal and phalangeal fractures. J Hand Surg Am 1998;23(5):827-32. Crossref

36. Jupiter JB, Koniuch MP, Smith RJ. Management of delayed union and nonunion of metacarpals and phalanges. $J$ Hand Surg Am 1985;10(4):457-66.

37. Kurzen P, Fusetti C, Bonaccio M, Nagy L. Complications after plate fixation of phalangeal fractures. J Trauma 2006;60(4):841-3. Crossref

38. Ring D. Malunion and nonunion of the metacarpals and phalanges. Instr Course Lect 2006;55:121-8. 